ФЕДЕРАЛЬНОЕ ГОСУДАРСТВЕННОЕ БЮДЖЕТНОЕ НАУЧНОЕ УЧРЕЖДЕНИЕ «ИНСТИТУТ ПЕДАГОГИКИ, ПСИХОЛОГИИ И СОЦИАЛЬНЫХ ПРОБЛЕМ»

\title{
ГЕНЕЗИС КОГНИТИВНОЙ ПАРАДИГМЫ ОБРАЗОВАНИЯ
}

Монография

Казань - 2021 


\title{
УДК 378
}

ББК 74

Г34

\section{Утверждено Ученым Советом ФГБНУ «Институт педагогики, психологии и социальных проблем»}

\author{
Рецензенты:
}

Бенин В.Л. - доктор педагогических наук, профессор

Щелкунов М.Д. - доктор философских наук, профессор, академик АН РТ

$\Gamma 34$ Генезис когнитивной парадигмы образования: монография / Е.Ю. Левина Р.Х. Гильмеева, А.Р. Камалеева, А.С. Кац, Л.Ю. Мухаметзянова, Е.Н. Прокофьева, О.В. Стукалова, Т.М. Трегубова, Л.А. Шибанкова; под научной редакцией Е.Ю. Левиной. - Казань: Институт педагогики, психологии и социальных проблем, 2021. - 240 c.

ISBN 978-5-89917-256-4

DOI 10.51379/j7741-0571-3535-w

В монографии представлены результаты фундаментальных исследований в сфере педагогической науки. Обоснованы современные образовательные тренды и раскрыты предпосылки становления когнитивной парадигмы образования, сформулированы ее сущности и категории. Раскрыта методология когнитивной педагогики как нового раздела педагогической теории и практики. Рассмотрен потенциал когнитивного развития человека в образовательном пространстве, представлены инструментарий когнитивной дидактики и когнитивного менеджмента, в основе которых - управление генерацией знаний и становление системы познания субъектов образования. Адресуется педагогам, психологам и другим представителям социогуманитарных направлений, преподавателям высшей школы, студентам и аспирантам педагогических специальностей, а также всем, кто интересуется теоретическими и практическими вопросами развития высшего образования.

ISBN978-5-89917-256-4

(C) ИППСП, 2020

(C) Коллектив авторов 


\section{Содержание}

Введение 5

ГАава 1. Трансформация высшего образования в 10 цифровую эпоху

(Мевина Е.Ю., Шибанкова А.А.)

ГАава 2. ПредпосыАки становАения когнитивной 23 парадигмы образования

(Иевина Е.Ю., Гильмеева Р.Х., Камалеева А.Р., Каи А.С., Трегубова Т.М., Шибанкова А.А.)

ГАава 3. Онтология когнитивной парадигмы 33 образования

(Иевина Е.Ю., Мухаметзянова А.Ю., Стукалова О.В., Шибанкова А.А.)

ГАава 4. Когнитивная педагогика: аксиологические 51 характеристики и инструментарий

4.1. Методология когнитивной педагогики

(Иевина Е.Ю., Мухаметзянова И.Ю., Камалеева А.Р., Стукалова О.В., Гильмеева Р.Х., Шибанкова А.А., Прокофьева Е.Н.)

4.2. Когнитивное моделирование как способ познания 68 педагогической реальности

(Мевина Е.Ю., Камалеева А.Р..)

Гцава 5. Научно-методическое обеспечение 77 когнитивного развития субъектов образования

5.1. Формирование гуманистической концептосферы 77 обучающихся

(Мухаметзянова А.Ю.)

5.2. Когнитивный диалог как человекообразующая стратегия 84 образования

(Мухаметзянова А.Ю.)

ГАава 6. Научно-методическое обеспечение 89 когнитивной дидактики

6.1. Категории когнитивной дидактики

(Камалеева А.P.)

6.2. Трансформация процесса обучения с позиций 92 когнитивной дидактики

(Камалеева А.Р.) 
6.3. Ценностно-смысловые приоритеты субъект-субъектного 106 взаимодействия в высшей школе

(Камалеева А.Р.)

6.4. Взаимодействие когнитивных стилей педагога и студентов 112 в образовательном пространстве высшей школы

(Kau A.C.)

ГАава 7. Научно-методическое обеспечение 128 когнитивного менеджмента

7.1. Концептуальные основания когнитивного менеджмента в 128 образовании

(Мевина Е.Ю.)

7.2. Инструментарий когнитивного менеджмента в образовании 139 (Иевина Е.Ю., Трегубова Т.М.)

ГАава 8. Когнитивный капитал образоватемьной 156 организации

8.1. Идентификация когнитивного капитала университета

156

(Иевина Е.Ю., Гильмеева Р.Х., Шибанкова А.А.)

8.2. Организационные ресурсы когнитивной капитализации 175 университета с позиции гуманитарных измерений

(Иевина Е.Ю., Гильмеева Р.Х., Шибанкова А.А.)

ГАава 9. Университет будущего: зона бцижайшего 202 развития

(Иевина Е.Ю., Прокофьева Е.Н.)

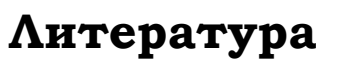

221

Сведения об авторах 


\section{Введение}

Монография подготовлена сотрудниками лаборатории «Когнитивная педагогика и цифровизация образования» ФГБНУ «Институт педагогики, психологии и социальных проблем». Ее содержание отражает результаты фундаментального исследования «Проблема современной методологии изучения формирования и развития человека в эпоху цифровизации» проводимого в рамках государственного задания Министерства науки и высшего образования РФ в течение последних трех лет.

Поставленная государством задача повышения социальной значимости образовательной системы диктует необходимость системных инноваций, формируя стратегические и тактические направления развития ее подсистем.

Особая роль в этих условиях у организаций высшего образования, долженствующих обеспечить конечный результат образования - формирование и развитие человеческого капитала социума.

Массовизация высшего образования, его востребованность обществом коренным образом трансформировали его миссию (развитие интеллектуального потенциала нации), видение (интеграция науки, образования и инноваций) и формат (расширение субъектности образовательных организаций высшего образования). Обобщенно, персонифицированная цель высшего образования профессиональная подготовка «идеала» человека (с учетом его личных способностей, потребностей, возможностей личностного, интеллектуального и физического развития), необходимого современному обществу. Возникновение новых условий, возможностей и потребностей (финансовых; нормативноправовых; научно-технических; организационных; информационных; мотивационных и др.) предопределяет поиск новых форм развития высшего образования, формирующего настоящее и будущее государства в социальноэкономическом и научно-технологическом контекстах.

Одним из решений представляется становление и распространение когнитивной парадигмы образования, базирующейся на обращении к многоуровневым способам, видам и технологиям мышления, восприятия и переработки информации в целях создания субъектом образования собственной системы генерации знаний и представлений в конкретной предметной области (личностной сфере обучающегося, личностно-профессиональной сфере деятельности педагога и сфере деятельности образовательной организации в целом), что обусловит возможность их непрерывного развития для продуктивной жизнедеятельности в сложном обществе с высокой неопределенностью. 
Монография состоит из 9 глав, последовательно раскрывающих сущностные характеристики новой когнитивной парадигмы образования и методологию ее практической реализации.

Е.Ю. Левина и Л.А. Шибанкова, проводя анализ современных мировых и страновых образовательных трендов, делают вывод о необходимости глобальной трансформации организационно-педагогических условий и целей высшего образования, отмечая при этом приоритетность Человека и гуманитарной направленности высшей школы, несмотря на новые форматы педагогических взаимодействий.

В поисках новых образовательных возможностей во второй главе монографии, авторы (Аевина Е.Ю., Гимьмеева Р.Х., Камалеева А.Р., Кац А.С.,

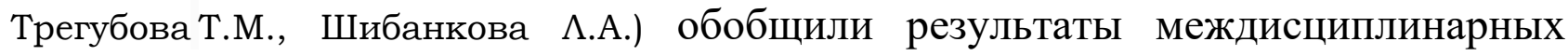
исследований в сфере когнитивистики (когнитивной психологии, когнитивной антропологии, когнитивной лингвистики, нейробиологии, информатики и компьютерных наук)- науки о познании, приобретении, получении, преобразовании и использования знаний. Обращение к этой сфере вызвано требованиями формирующегося общества знаний и новым вызовам к современному университету. Отмечая отсутствие системного внедрения феномена когнитивности в педагогику, как науку о воспитании и развитии человека, организационных формах обучения и управления этими процессами, мы определили необходимость теоретического обобщения когнитивной парадигмы образования и формирования теории когнитивной педагогики, способных решить поставленные перед образованием в эпоху цифровизации новые сложные задачи.

Онтология когнитивной парадигмы образования как совокупность основных позиций, сущностей и категорий раскрывается авторами (Левина Е.Ю., Мухаметзянова Л.Ю., Стукалова О.В., Шибанкова Л.А.) в третьей главе настоящей монографии, фиксируя метапринципы человекосообразности, природосообразности, социосообразности и культуросообразности в качестве базиса. Человек в современном образовании должен остаться центральной фигурой при использовании широчайших возможностей цифровизации, а педагогическое управление, прежде всего, должно быть гуманитарно-мотивированным. Этот процесс нагружает университеты новыми миссиями и ролями, одновременно повышая значимость университетов, работающих на будущее и отвечающих социальным ожиданиям.

В четвертой главе, ставя задачу формирования и развития механизмов познания и управления знаниями для всех субъектов (знания человека, педагогического сообщества и знания образовательной организации), Левина Е.Ю., Мухаметзянова Л.Ю., Камалеева А.Р., Стукалова О.В., Гильмеева Р.Х., и 
Шибанкова Л.А., детально описывают методологию когнитивной педагогики, опираясь на синтез философских, психологических, педагогических и гуманитарных подходов, систему знаний и технологий к разработке когнитивной основы образовательной деятельности, способствующей исследованию и развитию образовательных систем, субъектов образования, образовательных процессов и ситуаций в эпоху цифровизации. Здесь же А.Р. Камалеева и Е.Ю. Левина раскрывают потенциал когнитивного моделирования как поэтапного процесса разработки когнитивной модели педагогической системы, объекта, процесса или ситуации на основе знаний о психолого-педагогических закономерностях их функционирования и учета причинно-следственных цепочек, отражающих систему взаимодействия рассматриваемых компонентов. Полученные динамические модели способствуют познанию педагогической реальности и служат опорой для организационно-педагогических действий.

Пятая глава, написанная Л.Ю. Мухаметзяновой, посвящена педагогической интерпретации когнитивного развития Человека будущего. Автор отмечает, что необходимо усиление человекоориентированной составляющей высшего образования, которая входит в число определяющих факторов, способствующих повышению культурного и интеллектуального уровней обучающихся. Исследование строится на резервах гуманистической когниции и личностной концептосферы субъектов образования как интеграционной целостности культурных универсалий, личностных смысловых установок, эмоциональных ценностных коннотаций человека, составляющих сущность его личностно-профессиональной картины - образа мира. Когнитивный диалог субъектов образования предстает здесь как продуктивный тип добровольных равноправных педагогических отношений.

В шестой главе А.Р. Камалеева представляет развернутое научнометодическое обеспечение когнитивной дидактики, главным отличием которой является то, что в ней особое внимание уделяется изучению и развитию познавательных структур и инструментария познания человека, и уже потом, на этой основе - адаптация дидактических возможностей образования к конкретным условиях реализации образовательной деятельности. Интегрируя достижения традиционной и цифровой дидактики, предметных методик и педагогической психологии А.Р. Камалеева обосновывает ситуационно-событийный механизм становления личностных структур познания обучающихся в вузе. В контексте реализации образовательной деятельности (студент $\leftrightarrow$ преподаватель; преподаватель $\leftrightarrow$ группа студентов; преподаватель $\leftrightarrow$ образовательная среда $\leftrightarrow$ студент и проч.) раскрываются ценностно-смысловые приоритеты субъектсубъектного взаимодействия (А.Р. Камалеева) и особенности взаимодействия когнитивных стилей педагога и студентов (А.С. Кац). Их анализ и учет при 
преподавании предметных дисциплин позволяет усилить учебно-методический потенциал образовательной деятельности через уменьшение разрыва восприятий и приема-передачи учебной информации.

Седьмая глава монографии посвящена теории когнитивного менеджмента в образовании (Левина Е.Ю.), инструментарий которого позволяет осуществить управление организационно-педагогическими знаниями на всех уровнях (институциональном, структурном, процессном, педагогическом). Базируясь на поиске новых знаний и закономерностей функционирования образовательных систем, организаций, процессов и событий (data mining), осуществляется работа с большими данными (big data) в целях повышения управляемости образовательных систем, организаций и процессов (Левина Е.Ю.). Представленная в главе технология бенчмаркинга в образовании (Т.М. Трегубова) позволяет провести конкурентный анализ, измерения и сравнения результатов деятельности признанных лидеров - организаций высшего образования с целью поиска результативных моделей образования и лучших педагогических практик для дополнения собственных стратегий развития.

Необходимо признать, что будущее для высшей школы уже наступило университеты конкурируют с множественными образовательными ресурсами и между собой за формат знаний, компетенций, условий обучения транслируя собственную систему ценностей, недосягаемую без высшего образования и особого уникального образовательного пространства. В восьмой главе мы представляем новый формат «актива» высшего образования, способного повлиять на качество образовательной деятельности и ее результативность когнитивный капитал образовательной организации, синергетически объединяющий человеческий, интеллектуальный, социальный и организационный капиталы, образуя континуум, ограниченный пространством образовательной организации (Е.Ю. Левина, Л.А. Шибанкова, Р.Х. Гильмеева). Актуализируется исследовательский поиск организационных ресурсов когнитивной капитализации университета с позиций теории гуманитарных измерений: социальное взаимодействие и социальная ответственность университета (Р.Х. Гильмеева, Е.Ю. Левина); профессионально-корпоративная идентичность университета (Р.Х. Гильмеева); феномен «доверие» в педагогическом коллективе (Л.А. Шибанкова).

Монография завершается прогнозными идеями и раскрытием потенциальных возможностей развития университета будущего (Е.Ю. Левина, Е.Н. Прокофьева). Авторы рассматривают методологию развития образовательных экосистем как new normal образовательной деятельности, раскрывая понятия образовательной экологии, базируя их на постулатах когнитивной парадигмы образования. Сопоставляя мировые тренды и 
образовательные возможности российских университетов, обобщены стратегические установки развития отечественных университетов на ближайшее будущее.

Авторы представленного исследования адресуют свои материалы широкому кругу специалистов - работникам системы высшего образования, исследователям, интересующихся вопросами развития высшего образования в новом обществе знаний с позиций когнитивной междисциплинарности.

Е. Ю. Левина 
Подписано в печать 15.11.2021 г. Печать цифровая. Отпечатано с готового оригинал-макета. Гарнитура Times. Формат бумаги 60x90/16. Объем 15 п.л.

Тираж 300 экз.

Отдел научно-организационного обеспечения ФГБНУ «ИППСП» 420039, г. Казань, ул. Исаева, 12 тел. (843) 560-75-84 